Gut, 1979, 20, 709-715

\title{
Biochemical changes in the jejunal mucosa of dogs with naturally occurring exocrine pancreatic insufficiency
}

\author{
R. M. BATT ${ }^{1}$, B. M. BUSH, AND T. J. PETERS \\ From the Departments of Medicine, Royal Postgraduate Medical School, and \\ Royal Veterinary College, London
}

SUMMARY The roles of extracellular and intracellular mechanisms in the degradation of brush border proteins have been investigated by studying the small intestinal mucosa of dogs with naturally occurring exocrine pancreatic insufficiency. Peroral jejunal biopsies were homogenised and the organelles separated by isopycnic centrifugation on continuous sucrose density gradients. The distributions of marker enzymes for the principal subcellular organelles were determined in the gradients and related to the specific activities in the homogenates. There were increased activities of the brush border carbohydrases zinc-resistant $\alpha$-glucosidase, maltase and sucrase in the pancreatic insufficient animals, but no change in lactase activity. The activity of $\gamma$-glutamyl transferase was also higher in the affected group; the activities of two other brush border enzymes, alkaline phosphatase and leucyl- $\beta$-naphthylamidase, however, were unaltered. These findings with an increase in the modal density of the brush border from 1.20 to 1.22 are consistent with an enhanced glycoprotein content of the microvillus membrane. There were also rises in the activities of lysosomal enzymes. $\mathrm{N}$-Acetyl- $\beta$-glucosaminidase activity was increased in the soluble fractions and the percentage latent enzyme activity was reduced, findings indicative of an increased fragility of the lysosomal membrane. There were no marked alterations in the activities or density gradient distributions of marker enzymes for the other organelles, stressing the specificity of the changes in the brush borders and lysosomes. These findings are compatible with the degradation of certain exposed brush border proteins by pancreatic proteases and suggest that when this is defective, intracellular degradative mechanisms may be stimulated.

The enterocyte is a highly specialised cell involved in the terminal processing of nutrients and their transference from the lumen of the small intestine. Although the life span of this cell is relatively short, the protein content of the enterocyte is not static, proteins turning over at heterogeneous rates by a continuous process of synthesis and degradation (Alpers and Kinzie, 1973). A balance between these processes maintains the steady state level of individual proteins. Free ribosomes are responsible for the synthesis of intracellular proteins, whereas those destined for export or insertion into membranes are synthesised on the rough endoplasmic reticulum (Dallner et al., 1966). Control of synthesis, by the

${ }^{1}$ Present address: Division of Clinical Cell Biology, Clinical Research Centre, Watford Road, Harrow, Middlesex. Correspondence: Dr. R. M. Batt.

Received for publication 8 March 1979 regulation of genetic expression, may be achieved in a variety of ways at the transcriptional and posttranscriptional levels (Gelehrter, 1973) and may be influenced by exogenous stimuli such as corticosteroids (Baxter et al., 1972). Protein degradation and the controlling mechanisms, on the other hand, are not well understood, particularly in the enterocyte. The most specialised organelle, the brush border, is at the luminal surface and hence in a unique position potentially susceptible to both extracellular and intracellular degradative mechanisms. Pancreatic proteolytic enzymes (Alpers and Tedesco, 1975; Kwong et al., 1978) and lysosomal enzymes (Seetharam et al., 1976) are thought to play a part in the turnover of specific brush border proteins. This has been investigated in the present study by examining the biochemical changes in the jejunal mucosa at a subcellular level in dogs with naturally occurring exocrine pancreatic insufficiency. A pre- 
Table 1 Clinical details of pancreatic insufficient animals (male Alsatians), results of screening tests, and PABA in plasma and urine after oral dose of N-benzoyl-L-tyrosyl-PABA

\begin{tabular}{|c|c|c|c|c|c|c|c|}
\hline Group and case no. & $\begin{array}{l}\text { Age } \\
\text { (yr) }\end{array}$ & $\begin{array}{l}\text { Weight } \\
(k g)\end{array}$ & $\begin{array}{l}\text { Fat } \\
\text { absorption } \\
(\%)\end{array}$ & $\begin{array}{l}\text { Faecal fat } \\
(\text { g/day })\end{array}$ & $\begin{array}{l}\text { Faecal proteolytic } \\
\text { activity } \\
\text { (azo-casein units/g) }\end{array}$ & $\begin{array}{l}2 h \text { plasma } P A B A \\
(\mu \mathrm{mol} / I)\end{array}$ & $\begin{array}{l}6 \text { h urinary } \\
\text { excretion of } P A B A \\
(\% \text { of oral dose) }\end{array}$ \\
\hline \multicolumn{8}{|c|}{ Pancreatic insufficiency } \\
\hline 1 & 3 & 30 & 59 & $16 \cdot 0$ & $2 \cdot 5$ & $1 \cdot 2$ & $7 \cdot 3$ \\
\hline 2 & $2 \frac{1}{2}$ & 27 & 40 & $14 \cdot 4$ & 1.4 & $2 \cdot 3$ & $9 \cdot 6$ \\
\hline 3 & 5 & 37 & 72 & $13 \cdot 5$ & $3 \cdot 9$ & $2 \cdot 3$ & $12 \cdot 7$ \\
\hline 4 & 6 & 35 & 79 & $9 \cdot 8$ & $1 \cdot 5$ & $2 \cdot 8$ & $10 \cdot 1$ \\
\hline 5 & $2 \frac{1}{2}$ & 35 & 55 & $21 \cdot 2$ & 1.6 & - & - \\
\hline Control & & & $93 \cdot 8 \pm 0 \cdot 6(11)$ & $2 \cdot 2 \pm 0 \cdot 4(11)$ & $67 \cdot 2 \pm 12 \cdot 5(11)$ & $31 \cdot 8 \pm 3 \cdot 4(4)$ & $76 \cdot 3 \pm 3 \cdot 6(4)$ \\
\hline
\end{tabular}

Control data, with number of observations between parentheses, are presented as mean \pm SEM.

liminary report of this work has been published previously (Batt et al., 1979a).

\section{Methods}

GROUPS OF ANIMALS

Control animals were normal dogs with no functional or histological evidence of a jejunal abnormality. Exocrine pancreatic insufficiency was detected in animals presented for an investigation of diarrhoea and weight loss by the demonstration of severe steatorrhoea and negligible faecal proteolytic activity. The clinical details and results of the screening tests (Batt et al., 1979b) are shown in Table 1. The diagnosis was confirmed by the oral administration of N-benzoyl-L-tyrosyl-p-aminobenzoic acid, a substrate specific for chymotrypsin, and the subsequent estimation of plasma and urine p-aminobenzoic acid (PABA) (Batt et al., 1979b). The results (Table 1) show that at two hours normal animals achieve a plasma PABA concentration approximately 10 times greater than that of the animals with pancreatic insufficiency. The urinary excretion of PABA similarly distinguished between the two groups, most of the PABA being excreted in the control animals in a six hour period in contrast with the negligible amounts found in the urine of the affected animals.

ANALYTICAL SUBCELLULAR FRACTIONATION Peroral jejunal biopsies were obtained at the duodenal-jejunal flexure with a Watson paediatric capsule (Batt, 1979). Portions of the tissue were homogenised in sucrose $(0.3 \mathrm{~mol} / \mathrm{l})$ containing EDTA (1mmol/l) $\mathrm{pH} \mathrm{7 \cdot 4}$, and ethanol $(22 \mathrm{mmol} / \mathrm{l})$ (SVE medium) and a post-nuclear supernatant (PNS fraction) subjected to analytical subcellular fractionation in the Beaufay automatic zonal rotor as described previously (Batt and Peters, 1978a). After centifugation, alkaline phosphatase was assayed fresh and the remainder of the gradient then stored at $-20^{\circ} \mathrm{C}$. Results are expressed in the form of frequency-density histograms, the pooling and averaging of distributions being performed by computer (Leighton et al., 1968).

LATENT N-ACETYL- $\beta$-GLUCOSAMINIDASE Latent- $\mathrm{N}$-acetyl- $\beta$-glucosaminidase activity was determined by assaying this enzyme in the PNS fraction in SVE medium containing buffered substrate with (total activity) and without (free activity) Triton X-100 (100 mg/100 ml) (Batt and Peters, 1976).

Latent activity $(\%)=\frac{\text { Total activity }- \text { Free activity }}{\text { Total activity }} \times 100$

ANALYTICAL TECHNIQUES

Marker enzymes for the principal subcellular organelles were assayed as described previously (Batt and Peters, 1978a). Acid phosphatase was assayed with 4-methylumbelliferyl phosphate $(0.15 \mathrm{mmol} / \mathrm{l})$ in sodium acetate buffer $(0 \cdot 1 \mathrm{~mol} / \mathrm{l}), \mathrm{pH} 4 \cdot 0$, containing Triton X-100 (100 mg/100 ml). Maltase, sucrase, and lactase were assayed (Peters et al., 1976) in portions of biopsies collected in deionised water and disrupted in a Dounce homogeniser (Kontes Glass Co., Vineland, New Jersey, USA) with 20 strokes of a tight-fitting pestle (type B). Protein was determined according to Schacterle and Pollack (1973) with bovine serum albumin (Armour Pharmaceutical Co., Chicago, USA) as a standard. The unpaired Student's $t$ test was used to assess the significance of differences between the two groups.

\section{Results}

ENZYME ACTIVITIES

The specific activities of brush border enzymes in biopsies from control and pancreatic insufficient animals are shown in Table 2. There are significant increases in the activities of zinc-resistant $\alpha$-glucosidase, maltase, sucrase, and $\gamma$-glutamyl transferase in the affected animals, but no significant changes in 
Table 2 Activities (mUnits/mg protein) of brush border enzymes in biopsies from control and pancreatic insufficient animals

\begin{tabular}{|c|c|c|c|c|c|c|c|}
\hline Group & $\begin{array}{l}\text { Zinc-resistant } \\
\text { a-glucosidase }\end{array}$ & Maltase & Sucrase & Lactase & $\begin{array}{l}\text { Alkaline } \\
\text { phosphatase }\end{array}$ & $\begin{array}{l}\text { Leucyl- } \beta \\
\text { naphthylamidase }\end{array}$ & $\begin{array}{l}\gamma \text {-Glutamyl } \\
\text { transferase }\end{array}$ \\
\hline Control & $\begin{array}{l}6 \cdot 1 \pm 0 \cdot 3 \\
(14)\end{array}$ & $\begin{array}{l}336 \pm 24 \\
(9)\end{array}$ & $\begin{array}{l}62 \cdot 6 \pm 5 \\
(10)\end{array}$ & $\begin{array}{l}31 \cdot 4 \pm 3 \cdot 0 \\
(6)\end{array}$ & $\begin{array}{l}138 \pm 11 \\
(12)\end{array}$ & $\begin{array}{l}101 \pm 9 \cdot 6 \\
(14)\end{array}$ & $\begin{array}{l}10.9 \pm 0.6 \\
(13)\end{array}$ \\
\hline Pancreatic insufficiency & $\begin{array}{l}8 \cdot 1 \pm 0 \cdot 8 \\
(5)\end{array}$ & $\begin{array}{l}535 \pm 76 \\
(5)\end{array}$ & $\begin{array}{l}136 \pm 28 \\
(5)\end{array}$ & $\begin{array}{l}45 \cdot 7 \pm 9 \cdot 7 \\
(5)\end{array}$ & $\begin{array}{l}101 \pm 14 \\
(5)\end{array}$ & $\begin{array}{l}111 \pm 13 \\
(5)\end{array}$ & $\begin{array}{l}15 \cdot 5 \pm 1 \cdot 7 \\
(5)\end{array}$ \\
\hline Statistical significance (P) & 0.01 & 0.01 & 0.003 & $0 \cdot 2$ & $0 \cdot 1$ & 0.6 & 0.004 \\
\hline
\end{tabular}

Data are expressed as mean \pm SEM. The figures between parentheses indicate the number of observations.

the activities of lactase, alkaline phosphatase, or leucyl- $\beta$-naphthylamidase. The specific activities of marker enzymes for the other subcellular organelles are shown in Table 3 . The activity of 5 -nucleotidase, a basal-lateral membrane enzyme, is unaltered. There are, however, large increases in the activities of the acid hydrolases $\mathrm{N}$-acetyl- $\beta$-glucosaminidase and acid phosphatase in the pancreatic insufficient animals, although $\alpha$-mannosidase activity is unchanged. Malate dehydrogenase, with both soluble and mitochondrial components, tris-resistant $\alpha$-glucosidase, an endoplasmic reticular enzyme, and catalase, a peroxisomal enzyme, have similar activities in the two groups. Latent $\mathrm{N}$-acetyl- $\beta$-glucosaminidase activity, a measure of lysosomal integrity, is significantly reduced in the animals with pancreatic insufficiency compared with the control.

\section{SUBCELLULAR FRACTIONATION STUDIES}

The relative specific activities and density gradient distributions of the principal marker enzymes in jejunal biopsies from control and pancreatic insufficient animals are compared in the Figure. The distributions of these enzymes in the normal dog have been reported previously (Batt and Peters, 1978a).

The increase in zinc-resistant $\alpha$-glucosidase activity in the affected animals is almost entirely associated with the brush border. This organelle shows a distinct shift in modal density from 1.20 in the control to 1.22 in the pancreatic insufficient group, a change also reflected in the distributions of the other three brush border enzymes alkaline phosphatase, leucyl- $\beta$-naphthylamidase and $\gamma$-glutamyl transferase. Although the activities of alkaline phosphatase and leucyl- $\beta$-naphthylamidase are not altered, the enhanced activity of $\gamma$-glutamyl transferase in the affected animals is clearly associated with the brush border.

The distributions of 5 '-nucleotidase (basal-lateral membrane) are not markedly different comparing the two groups but there is a small shift in modal density from a value of 1.11 in the control to 1.12 in the pancreatic insufficient animals. The subcellular distributions of $\mathrm{N}$-acetyl- $\beta$-glucosaminidase, in contrast, are strikingly different between the two groups. Although the particulate activities associated with lysosomes are almost identical, there is a dramatic increase in soluble enzyme activity in the pancreatic insufficient group. The activities and distributions of the other marker enzymes malate dehydrogenase (mitochondria-cytoplasm) and tris-resistant $\alpha$-glucosidase (endoplasmic reticulum) and of catalase (peroxisomes, not shown) revealed negligible differences between the two groups.

\section{Discussion}

The role of pancreatic enzymes in the turnover of brush border proteins has been investigated by studying the small intestinal mucosa of dogs with naturally occurring exocrine pancreatic insufficiency.

Table 3 Activities (mUnits/mg protein) of marker enzymes and percent latent $N$-acetyl- $\beta$-glucosaminidase activity in biopsies from control and pancreatic insufficient animals

\begin{tabular}{|c|c|c|c|c|c|c|c|c|}
\hline Group & 5 '-Nucleotidase & $\begin{array}{l}N \text {-acetyl- } \beta \\
\text { glucosaminidase }\end{array}$ & $\begin{array}{l}\text { Acid } \\
\text { phosphatase }\end{array}$ & $\alpha$-Mannosidase & $\begin{array}{l}\text { Malate } \\
\text { dehydrogenase }\end{array}$ & $\begin{array}{l}\text { Tris-resistant } \\
\text { a-glucosidase }\end{array}$ & Catalase & $\begin{array}{l}\text { Latent } N \text {-acetyl- } \\
\beta \text {-glucosaminidase }\end{array}$ \\
\hline Control & $\begin{array}{l}2 \cdot 97 \pm 0.28 \\
(9)\end{array}$ & $\begin{array}{l}3.57 \pm 0.22 \\
(13)\end{array}$ & $\begin{array}{l}3.75 \pm 0.35 \\
(10)\end{array}$ & $\begin{array}{l}1 \cdot 17 \pm 0 \cdot 10 \\
(14)\end{array}$ & $\begin{array}{l}2464 \pm 280 \\
(9)\end{array}$ & $\begin{array}{l}0.70 \pm 0.04 \\
(13)\end{array}$ & $\begin{array}{l}8 \cdot 6 \pm 0 \cdot 76 \\
(13)\end{array}$ & $\begin{array}{l}70 \cdot 1 \pm 1 \cdot 2 \\
(11)\end{array}$ \\
\hline $\begin{array}{l}\text { Pancreatic } \\
\text { insufficiency }\end{array}$ & $\begin{array}{l}2.41 \pm 0.64 \\
(5)\end{array}$ & $\begin{array}{l}5 \cdot 26 \pm 0 \cdot 91 \\
(5)\end{array}$ & $\begin{array}{l}6.53 \pm 0.95 \\
(5)\end{array}$ & $\begin{array}{l}1 \cdot 15 \pm 0 \cdot 16 \\
(5)\end{array}$ & $\begin{array}{l}2561 \pm 520 \\
(5)\end{array}$ & $\begin{array}{l}0 \cdot 75 \pm 0 \cdot 1 \\
(5)\end{array}$ & $\begin{array}{l}8 \cdot 0 \pm 1 \cdot 7 \\
(5)\end{array}$ & $\begin{array}{l}55 \cdot 3 \pm 5 \cdot 8 \\
(5)\end{array}$ \\
\hline $\begin{array}{l}\text { Statistical } \\
\text { significance } \\
\text { (P) }\end{array}$ & 0.4 & 0.02 & 0.005 & 0.9 & 0.9 & 0.6 & 0.7 & 0.003 \\
\hline
\end{tabular}

Data are expressed as mean \pm SEM. The figures between parentheses indicate the number of observations. 


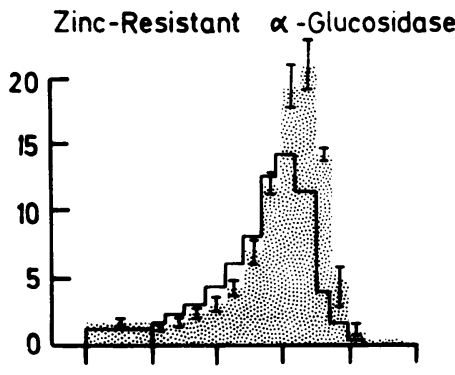

5 ' Nucleotidase
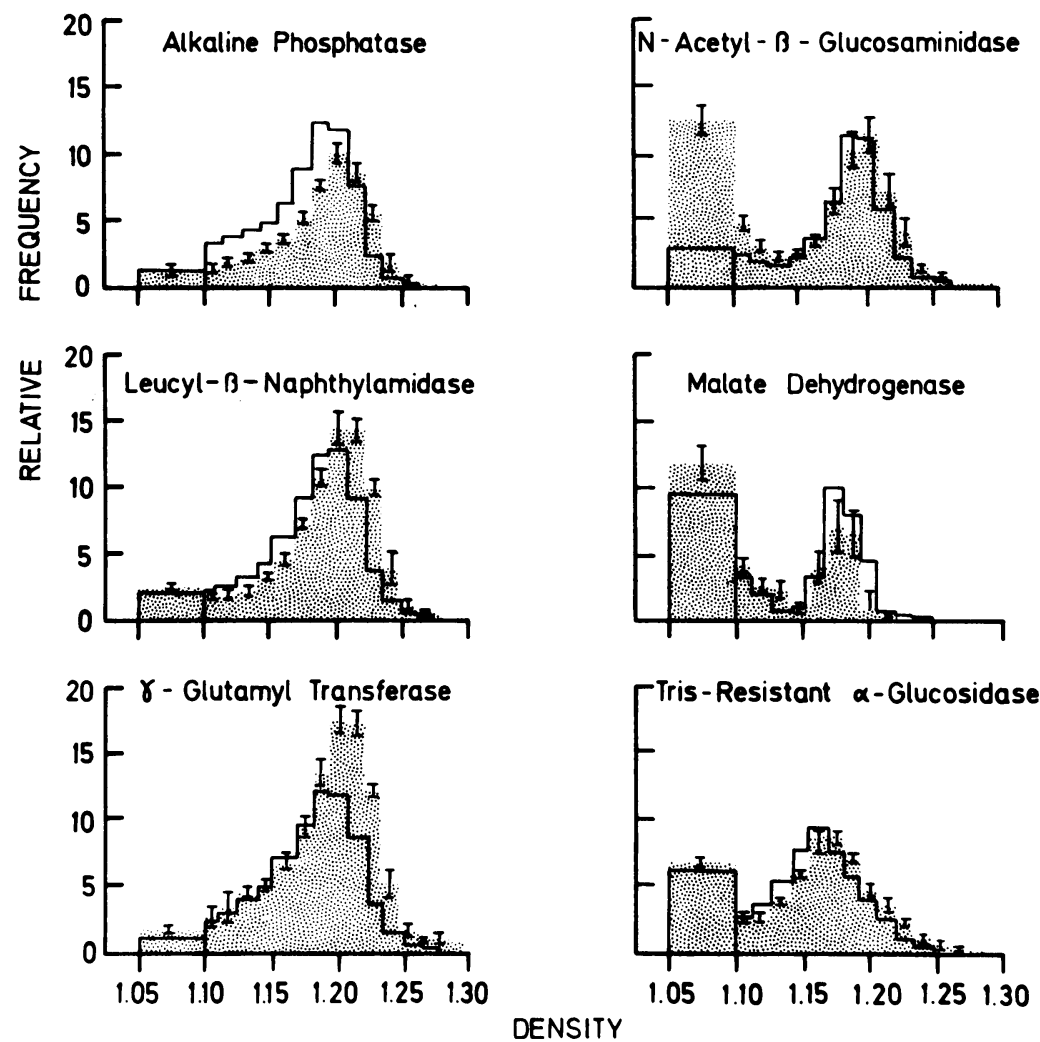

Figure Isopycnic centrifugation of PNS fraction from jejunal biopsies of control (solid line) and pancreatic insufficient animals (stippled). Graphs, of averaged data from at least three experiments, show the relative

frequency-density distributions of eight marker enzymes. For each enzyme the areas of the distributions comparing the two groups are proportional to enzyme specific activity. Frequency is defined as that portion of total recovered activity present in an individual fraction divided by the density span covered by that fraction. Relative frequency (mean $\pm S E M$ ) was derived by multiplying the frequency data for the pancreatic insufficient animals by the relative specific activity (mUnits/mg protein) of the pancreatic compared with the control animals. The percentage recoveries for the control and pancreatic insufficient animals, respectively, with the relative specific activities between parentheses, are: zinc-resistant $\alpha$-glucosidase 81, $83(1 \cdot 3)$; alkaline phosphatase 58, $77(0.7)$; leucyl- $\beta$-naphthylamidase 79, 76 (1.1); $\gamma$-glutamyl transferase 84, 87 (1.4); 5 -nucleotidase $79,129(0 \cdot 8) ; N$-acetyl- $\beta$-glucosaminidase $68,68(1 \cdot 5) ;$ malate dehydrogenase 87, $60(1 \cdot 0)$; tris-resistant $\alpha$-glucosidase 107, $95(1 \cdot 1)$. 
Biochemical characterisation of the enterocyte at a subcellular level has permitted an examination of the consequences of pancreatic insufficiency not only on the microvillus membrane but also on the other organelles of this cell.

Pancreatic degenerative atrophy in the dog is a well-recognised naturally occurring condition with a predisposition for the Alsatian or German Shepherd Dog (Hill et al., 1971). Histologically, there is a close similarity to the exocrine pancreatic insufficiency reported in CBA/J mice (Eppig and Leiter,1977) where there is a degeneration of acinar tissue without a severe inflammatory involvement and a retention of the islets of Langerhans, major ducts, vessels, and nerves. The present study emphasises how little functional acinar tissue remains in the dogs with exocrine insufficiency, the urine recovery of PABA after oral peptide being almost as low as in dogs with the pancreatic duct ligated (Imondi et al., 1972). In common with the mouse model, the lack of distinct endocrine abnormalities limits any effects on the small intestine which may be due to diabetes (Olsen and Korsmo, 1975).

The dogs with pancreatic insufficiency were found to have marked and quite specific changes in the brush borders of the jejunal enterocytes. The modal density of this organelle was increased and accompanied by enhanced activities of the carbohydrases zinc-resistant $\alpha$-glucosidase, maltase, and sucrase. The activity of $\gamma$-glutamyl transferase was also higher in the affected animals than in the control; the activities of both alkaline phosphatase and leucyl- $\beta$ naphthylamidase, however, were essentially unaltered. These findings are consistent with previous studies both in man (Arvanitakis and Olsen, 1974) and the experimental animal (Alpers and Tedesco, 1975; Kwong et al., 1978) implicating pancreatic enzymes in the normal turnover of the microvillus membrane. Low intraluminal concentrations of pancreatic enzymes could result in a decreased degradation-and thus increased brush border content-of enzymes normally susceptible to this attack. This susceptibility, in turn, must depend on the accessibility of the appropriate peptide bonds to these proteolytic enzymes and their importance in determining either the attachment of the brush border enzyme to the microvillus membrane or its active three-dimensional conformation.

Biochemical studies (Eichholz, 1968; Critchley et al., 1975; Louvard et al., 1975) indicate that, with the exception of trehalase, the carbohydrases are located at the external surface of the microvillus membrane, a position most vulnerable to the activity of pancreatic enzymes, and that they may be released from the membrane readily by pancreatic proteases (Alpers and Tedesco, 1975). Alkaline phosphatase
(Batt and Peters, 1978b) and leucyl- $\beta$-naphthylamidase (Louvard et al., 1976), in contrast, appear to be intrinsic membrane proteins which are more embedded in the microvillus membrane and consequently much less susceptible to release either by the action of papain or detergent (Eichholz, 1968; Critchley et al., 1975; Louvard et al., 1975). Indeed, pancreatic enzymes have been found to release negligible amounts of alkaline phosphatase activity from the brush border after incubation in vitro. Thus, in the present study, the enhanced activities of zincresistant $\alpha$-glucosidase, maltase, and sucrase but unaltered activities of alkaline phosphatase and leucyl- $\beta$-naphthylamidase in the pancreaticinsufficient animals may be explained by the differences in the localisation and orientation of these enzymes in the brush border membrane. The spatial arrangement of $\gamma$-glutanyl transferase in the microvillus membrane is less well understood; this study, however, suggests a susceptibility to pancreatic enzymes and therefore a significant exposed component in the brush border of the dog.

There was little alteration in either the enzyme content or density of the basal-lateral membranes in the pancreatic insufficient animals, thus emphasising the specificity of the changes at the luminal surface of the plasma membrane of the enterocyte. There were, however, distinct effects on the acid hydrolases. The activities of both $\mathrm{N}$-acetyl- $\beta$-glucosaminidase and acid phosphatase were raised, although $\alpha$-mannosidase activity was unchanged. For N-acetyl- $\beta$ glucosaminidase this increase was almost entirely associated with the soluble fractions of the density gradient, a finding confirmed by demonstrating a reduction in the percentage latent enzyme activity. This suggests either that a soluble non-lysosomal component of this enzyme activity is specifically raised, or, a more likely interpretation, that the lysosomes have an increased fragility.

The possible functions of lysosomes, particularly the roles of heterophagy and autophagy, in relation to cellular economy have been discussed by de Duve and Wattiaux (1966). There is considerable evidence for the fusion of endocytic vesicles with lysosomes (Miller and Palade, 1964; de Duve and Wattiaux, 1966) and it has been suggested that this may be associated with the recycling of constituents of the plasma membrane (Silverstein et al., 1977; Werb and Cohn, 1972). The specific part lysosomes play in the turnover of the brush border membrane is not known; there is, however, good evidence for endocytosis by the enterocyte and the subsequent fusion of vesicle and lysosomal membranes (Walker and Isselbacher, 1974). The ability of lysosomal enzymes to degrade microvillus membrane proteins appears to be limited (Seetharam et al., 1975), so that an increase 
in the protein content of the brush border, associated with decreased extracellular proteolysis, could result in the excessive accumulation of material within the lysosomes. In common with other conditions where this occurs, an enhancement in the fragility of the lysosomal membrane may result that is associated with an increase in the activities of specific lysosomal enzymes (Seymour and Peters, 1978).

An excessive uptake of macromolecules from the lumen of the small intestine could have the same consequences. A reduction in the concentration of pancreatic enzymes will increase the number of macromolecules, including antigen and antigenantibody complexes (Walker et al., 1975), at the surface of the enterocyte. This provides the opportunity for an enhanced absorption of these molecules (Walker and Isselbacher, 1974) and could result in an accumulation in the lysosomes and hence damage to the surrounding membrane.

There was little change in either the activities or density gradient distributions of marker enzymes for the mitochondria or peroxisomes. This was also true for particulate tris-resistant $\alpha$-glucosidase activity, suggesting that there was no major change in the endoplasmic reticulum and being consistent with the hypothesis that a decreased rate of degradation is responsible for the increased activities of specific brush border enzymes. This is in contrast with the increased activities in the prednisolone-treated animal, where a proliferation of the rough endoplasmic reticulum suggests an enhanced rate of synthesis of brush border enzymes and carrier proteins (Batt and Peters, 1976; Batt et al., 1978).

A study of exocrine pancreatic insufficiency in the dog has revealed highly specific changes in the brush border membrane and evidence of altered intracellular degradative mechanisms in response to decreased intraluminal concentrations of proteolytic enzymes. Further investigation of this condition should provide additional information on the biochemical and physiological interactions between the pancreas and the small intestine.

The authors thank the members of the Experimental Surgery Unit at the Royal Postgraduate Medical School, particularly Ms M. Bowden, and the staff at the Beaumont Animal Hospital, Royal Veterinary College, for their collaborative help, Mr.P. White for technical assistance, and Ms J. de Luca for typing the manuscript. The generous support of The Wellcome Trust is gratefully acknowledged.

\section{References}

Alpers, D. H., and Kinzie, J. L. (1973). Regulation of small intestinal protein metabolism. Gastroenterology, 64, 471-496.
Alpers, D. H., and Tedesco, F. J. (1975). The possible role of pancreatic proteases in the turnover of intestinal brush border proteins. Biochimica et Biophysica Acta, 401, 28-40.

Arvanitakis, C., and Olsen, W. A. (1974). Intestinal mucosal disaccharidases in chronic pancreatitis. American Journal of Digestive Diseases, 19, 417-421.

Batt, R. M. (1979), Techniques for single and multiple peroral jejunal biopsy in the dog. Journal of Small Animal Practice, 20, 259-268.

Batt, R. M., Bush, B. M., and Peters, T. J. (1979a). Biochemical changes in the jejunal mucosa of dogs with exocrine pancreatic insufficiency (Abstract). Clinical Science and Molecular Medicine, 56, 12P.

Batt, R M., Bush, B. M., and Peters, T. J. (1979b). A new test for the diagnosis of exocrine pancreatic insufficiency in the dog. Journal of Small Animal Practice, 20, 185-192.

Batt, R. M., and Peters, T. J. (1976). Effects of prednisolone on the small intestinal mucosa of the rat. Clinical Science and Molecular Medicine, 50, 511-523.

Batt, R. M., and Peters, T. J. (1978a). Subcellular fractionation studies on peroral jejunal biopsies from the dog. Research in Veterinary Science, 25, 94-100.

Batt, R. M., and Peters, T. J. (1978b). Analytical subcellular fractionation studies on enterocytes from the jejunum and ileum of the rat and some properties of brush-border alkaline phosphatase. Clinical Science and Molecular Medicine, 55, 157-165.

Batt, R. M., Wells, G., and Peters, T. J. (1978). The effects of prednisolone on the rat enterocyte at a subcellular level. Clinical Science and Molecular Medicine, 55, 435-443.

Baxter, J. D., Rousseau, G. G., Benson, M. C., Garcea, R. L., Ito, J., and Tomkins, G. M. (1972). Role of DNA and specific cytoplasmic receptors in glucocorticoid action. Proceedings of the National Academy of Sciences of the USA, 69, 1892-1896.

Critchley, D. R., Howell, K. E., and Eichholz, A. (1975). Solubilization of brush borders of hamster small intestine and fractionation of some of the components. Biochimica et Biophysica Acta, 394, 361-376.

Dallner, G., Siekevitz, P., and Palade, G. E. (1966). Biogenesis of endoplasmic reticulum membranes. I. Structural and chemical differentiation in developing rat hepatocyte. Journal of Cell Biology, 30, 73-96.

de Duve, C., and Wattiaux, R. (1966). Functions of lysosomes. Annual Review of Physiology, 28, 435-492.

Eichholz, A. (1968). Studies on the organization of the brush border in intestinal epithelial cells. V. Subfractionation of enzymatic activities of the microvillus membrane. Biochimica et Biophysica Acta, 163, 101-107.

Eppig, J. J., and Leiter, E. H. (1977). Exocrine pancreatic insufficiency syndrome in CBA/J mice. American Journal of Pathology, 86, 17-30.

Gelehrter, T. D. (1973). Mechanisms of hormonal induction of enzymes. Metabolism, 22, 85-100.

Hill, F. W. G., Osborne, A. D., and Kidder, D. E. (1971). Pancreatic degenerative atrophy in dogs. Journal of Comparative Pathology, 81, 321-330.

Imondi, A. R., Stradley, R. P., and Wolgemuth, R. (1972). Synthetic peptides in the diagnosis of exocrine pancreatic insufficiency in animals. Gut, 13, 726-731.

Kwong, W. K. L., Seetharam, B., and Alpers, D. H. (1978). Effect of exocrine pancreatic insufficiency on small intestine in the mouse. Gastroenterology, 74, 1277-1282.

Leighton, F., Poole, B., Beaufay, H., Baudhuin, P., Coffey, J. W., Fowler, S., and de Duve, C. (1968). The large-scale separation of peroxisomes, mitochondria, and lysosomes from the livers of rats injected with Triton WR 1339. Journal of Cell Biology, 37, 482-513.

Louvard, D., Maroux, S., Vannier, C., and Desnuelle, P. (1975). Topological studies on the hydrolases bound to the 
intestinal brush border membrane. I. Solubilization by papain and Triton X-100. Biochimica et Biophysica Acta, 375, 236-248.

Louvard, D., Semeriva, M., and Maroux, S. (1976). The brush-border intestinal aminopeptidase, a transmembrane protein as probed by macromolecular photolabelling. Journal of Molecular Biology, 106, 1023-1035.

Miller, F., and Palade, G. E. (1964). Lytic activities in renal protein absorption droplets. An electron microscopical cytochemical study. Journal of Cell Biology, 23, 519-552.

Olsen, W. A., and Korsmo, H. (1975). Enhancement of intestinal sucrase activity in experimental diabetes: the role of intraluminal factors. Journal of Laboratory and Clinical Medicine, 85, 832-837.

Peters, T. J., Batt, R. M., Heath, J. R., and Tilleray, J. (1976). The micro-assay of intestinal disaccharidases. Biochemical Medicine, 15, 145-148.

Schacterle, G. R., and Pollack, R. L. (1973). A simplified method for the quantitative assay of small amounts of protein in biologic material. Analytical Biochemistry, 51, 654-655.

Seetharam, B., Grimme, N., Goodwin, C., and Alpers, D. H.
(1976). Differential sensitivity of intestinal brush border enzymes to pancreatic and lysosomal proteases. Life Sciences, 18, 89-95.

Seymour, C. A., and Peters, T. J. (1978). Organelle pathology in primary and secondary haemochromatosis with special reference to lysosomal changes. British Journal of Haematology, 40, 239-253.

Silverstein, S. C., Steinman, R. M., and Cohn, Z. A. (1977). Endocytosis. Annual Review of Biochemistry, 46, 669-772.

Walker, W. A., and Isselbacher, K. J. (1974). Uptake and transport of macromolecules by the intestine. Possible role in clinical disorders. Gastroenterology, 67, 531-550.

Walker, W. A., Wu, M., Isselbacher, K. J., and Bloch K. J. (1975). Intestinal uptake of macromolecules. IV. The effect of pancreatic duct ligation on the breakdown of antigen and antigen-antibody complexes on the intestinal surface. Gastroenterology, 69, 1223-1229.

Werb, Z., and Cohn, Z. A. (1972). Plasma membrane synthesis in the macrophage following phagocytosis of polystyrene latex particles. Journal of Biological Chemistry, 247, 2439-2446. 